\title{
ACUTE LAMOTRIGINE OVERDOSE IN ADULTS: A CASE REPORT
}

\author{
Janicijevic Katarina ${ }^{1}$, Kovacevic Zoran ${ }^{2}$, Glisic Milos ${ }^{3}$, Janicijevic Petrovic A. Mirjana ${ }^{4}$, \\ Lazarevic Tatjana ${ }^{5}$

\begin{abstract}
'Department of Social Medicine, Faculty of Medical Sciences University of Kragujevac, Serbia
${ }^{2}$ Department of Internal medicine, Clinical Centre Kragujevac, in Kragujevac, Serbia

${ }^{3}$ Department of Physiology, Faculty of Medical Sciences University of Kragujevac, Serbia

${ }^{4}$ Department of Ophthalmology, Faculty of Medical Sciences University of Kragujevac, Serbia
\end{abstract} \\ ${ }^{5}$ Department of Internal medicine, Faculty of Medical Sciences University of Kragujevac, Serbia
}

\section{Apstrakt}

Introduction: Self-treatment with Lamotrigine rarely ends with toxicity, regardless of the suicidal intentions of the patient. The authors hereby present an illustrative case of the patient who has been treated with epilepsy therapy with Dandy-Walker syndrome and congenital epidermolysis bullosa (potentially skin-unwanted). Lamotrigine is a phenyltriazine-class, broad-spectrum antiepileptic and therapy of bipolar depression. Dandy-Walker syndrome is a pathological entity and represents the set of developmental, cerebral, but also other abnormalities of the organism. Epidermolysis bullosa is a hereditary, non-inflammatory skin disease with a mucous membrane of characteristic "bubbles".

Case report: Our patient, a 37-year-old male was first admitted to the hospital department of Urgent Medicine of Clinical Center Kragujevac because he consumed two boxes of Lamotrigine tablets. In the receiving clinic, the patient showed respiratory failure and was urgently intubated. From medical documentation and hetero-anamnesis (obtained by his father), the authors found out that he was treated for epilepsy, Dandy-Walker syndrome, and congenital epidermolysis bullosa, which deteriorated with the use of Lamotrigine through potentially undesirable skin effects. During clinical observation, a lavage of gastric contents was conducted. The medical coal was used via nasogastric intubation as a detoxification method because of the patient's comatose state. Causative metabolic pathway of lamotrigine, the hemodialysis was performed.

Conclusion: The case report of our patient points to the necessity of a multidisciplinary approach of the expert team, consisting of the clinical pharmacologist and toxicologist, neurologist, dermatologist, nephrologists, and other specialists, if necessary. Patients with Dandy-Walker syndrome require adequate socio-medical care.

Keywords: Lamotrigine, acute overdose, Dandy-Walker syndrome, congenital epidermolysis bullosa, clinical manifestations, diagnostic and therapeutic interventions

\section{INTRODUCTION}

Self-treatment with Lamotrigine rarely ends with overdose toxicity, regardless of the suicidal intentions of the patient. The patient from our case study is a 37-year-old male who was hospitalized because of a Lamotrigine overdose. He was sent to Clinical Center Kragujevac from the Health Center of Arandjelovac. We hereby present the illustrative case of the patient who has been treated for epilepsy (with potentially unwanted therapy), Dandy-Walker syndrome, and congenital epidermolysis bullosa. He used Lamotrigine for treatment (Phenyltriazine-class), a broad-spectrum antiepileptic drug along with the therapy for bipolar depression. Dandy-Walker syndrome is the pathological entity of developmental abnormalities in the brain and other organs. Bullous epidermolysis is a hereditary, non-inflammatory skin disease with persistent mucous membrane, characteristic as "bubbles". According to action-mechanism, Lamotrigine blocks sodium channels, and during clinical exposure, it can cause, toxicity in overdose $(\geq 23 \mathrm{mcg} / \mathrm{mL})$ as the newer genera- 
tion of anti-epileptics (respiratory depression, cardiac arrest, coma, and death) which required endotracheal intubation as an effective procedure in overdose cases (1). This syndrome diagnosis (her father provided diagnosis) was followed by clinical symptoms, that have previously been reported as epilepsy, intellectual incompetence, and other. The case report illustrates the complexity of the observation of the syndrome in an adult male, which presents the diagnostic and the therapeutic challenge in acute overdose with Lamotrigine. The constellation of symptoms and structural abnormalities of the brain should be taken into consideration when dealing with patients with neuropsychiatric manifestations, systemic diseases, and specific skin diseases, especially if diagnosed in childhood and adolescence and chronically treated with Lamotrigine.

\section{CASE REPORT}

A patient of 37 years was conducted as an emergency admission to The Department of Urgent Medicine of Clinical Center Kragujevac in Kragujevac because he had consumed two boxes of Lamotrigine tablets (overdose). From his medical documentation and hetero-anamnesis, the authors discovered that he was treated for epilepsy, Dandy-Walker syndrome, and congenital (epidermolysis bullosa), which worsened with the use of Lamotrigine, through undesirable skin effects.

At admission, the patient was disoriented, agitated, a-febrile of medium osteomuscular build and nutrition, no signs of hemorrhagic syndrome and peripheral adenopathy. Auscultatory over lungs weakened respiratory murmur. Rhythmic heart action, well-audible tones, no noise; the abdomen was soft, palpably painless, without defense, and peritoneal reaction. Bullous changes bleeding when touched were seen on the mucous membrane of the oral cavity, two erosions covered with thin crusts were seen on the inner side of the left hand, and one bulla filled with serous contents was observed in the pubic area (Figure 1).

Figure 1. Epidermolysis bullosa (Lamotrigine-overdose), as potentially undesirable skin effects.

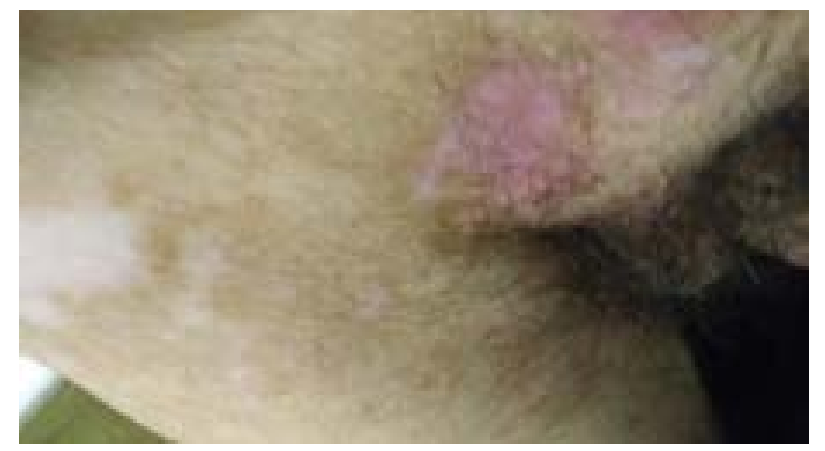

Initially, due to the patient's non-cooperation, it was not possible to perform an electrocardiographic recording, which was subsequently performed and shallow negative T-waves from V1 to V4 were recorded, with sinus rhythm and heart rate $90 / \mathrm{min}$. Immediately, after the examination, breathing ceased, and the patient was urgently intubated and connected to an assisted ventilation device. Biochemical laboratory tests were regular except for inflammations parameters. The gas analyses indicated hypoxemia (Table 1).

During the clinical observation, the lavage of gastric contents was performed. Medical coal was used via nasogastric intubation as a detoxification method since the patient was in a comatose state. Causative metabolic pathway of Lamotrigine the double hemodialysis with the minimal ultrafiltration was also performed.

Additionally, a computerized tomography (CT) scan of the brain discovered: cerebral hemiatrophy including cerebellum hypo-atrophy with skull thickening/widening of the vermis (dysgenesis) and communication of ventricle (IV) with arachnoid-cisternal - spaces in fossa crani posterior (Figure 2).

As for clinical characteristics, a radiography of the heart and lungs performed several times showed regular findings. The concentration of Lamotrigine in blood was determined at a reference institution in Belgrade of Serbia (toxicological laboratory of Military Medical Academy), which was elevated to a toxic concentration of $20.82 \mathrm{~g} / 1$ (reference value $4-11 \mathrm{~g} / \mathrm{l}$ ).

On the fourth day of hospitalization, the state of consciousness stabilized, and gas exchange normalized, after which the patient was separated from assisted ventilation and extubated. The patient had normal vital signs: blood pressure was $110 / 55 \mathrm{~mm} \mathrm{Hg}$, heart rate was $54 / \mathrm{min}$, respiratory rate was $15 / \mathrm{min}$, and the temperature was about $36^{\circ} \mathrm{C}$. Ophthalmological signs showed minor nystagmus, degenerative myopia, and characteristic retinal defects with vitreous fenestrated membranes in the retinal periphery. The virus tests were negative, as well as the psychoactive substance test. Due to clinical improvement and normalization of all basic-laboratory analyzes, so no control level of Lamotrigine was performed. Finally, since Lamiktal ${ }^{\circledR}$ tablets (brand name of medicament) can cause skin changes exacerbating its condition, the doctors decided to opt for gradual exclusion of this medicament while continuing the treatment of epilepsy with $\mathrm{Ke}$ pra ${ }^{\circledR}$ tablets (brand name). To treat depression, Elice ${ }^{\circledR}$ tablets (brand name) were introduced. The patient was discharged for 16 days of hospitalization in good general condition. 
Figure 2. The computerized tomography with neuroanatomic structural changes in

Dandy-Walker syndrome.
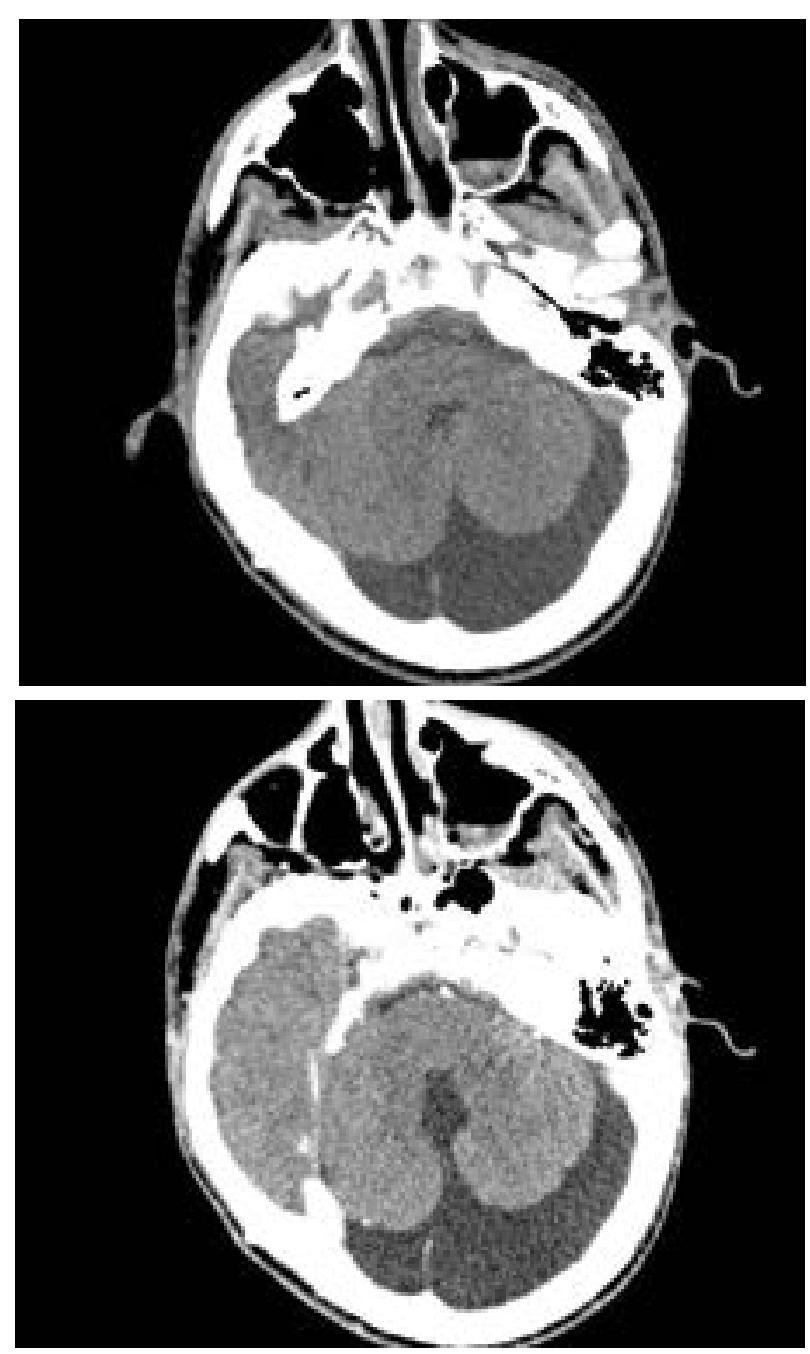

\section{DISCUSSION}

Our case reported the illustrates-nature of Dandy-Walker syndrome and congenital epidermolysis bullosa in an adult male and represented the diagnostic and therapeutic challenge in acute overdose of Lamotrigine. Our patient was of depressed mood resulting in suicidal ideation/suicidal attempts and developed the status of epileptic.

The spectrum of clinical effects of Lamotrigine in acute overdose was not precisely established. Several cases of overdose had serious effects such as coma, respiratory depression, and intraventricular conduction disturbances.

Serum evaluation revealed high Lamotrigine levels without any other etiology for mental dysfunction. After the prompt supportive treatment with early intubation, use of potassium chloride for hypokalemia, and the administration of sodium bicarbonate, the condition of the overdosed patients improved (2). Encephalopathy is the secondary cause of serious Lamotrigine-toxicity, as the clinical manifestation (3). Lamotrigine-overdose was usually benign, mild, or with no toxicity, but large exposures were associated with severe central nervous system depression, cardiac conduction delays, seizures, and death (4).

Other toxic effects include hypersensitivity reactions, QRS-complex prolongations, rhabdomyolysis, serotonin syndrome, seizures, and/or agitation (5), with these effects of the other author's opinion, we also agree. Today, many document treatment-refractory Lamotrigine cardiotoxicity among dogs by applying intra-lipid emulsion therapy (6). Dandy-Walker malformation or syndrome occurs sporadically. Some patients remain clinically asymptomatic for years, while others may exhibit a variety of co-morbidities leading to earlier diagnosis and multidisciplinary research. Treatments are generally focused on posterior fosse symptoms, often including surgical interventions, like ventriculoperitoneal and cystoperitoneal shunting (7), but the surgical possibility of intervention was excluded from our patient.

In case reports, many authors described the neuropsychological and behavioral profile of patients, usually in adult males (8), as in our case report.

Brain computed tomography and brain magnetic resonance imaging have shown cyst in posterior fosse, hydrocephalus, hypoplasia of corpus callosum, syringomyelia, absence of cerebellar vermis, etc. Surgery involving arachnoid adhesiolysis and endoscopic third ventriculostomy was performed (9).

The progression of associated morbidities in Dandy-Walker syndrome requires an early, multidisciplinary diagnosis, so that clinically asymptomatic cases, over the many years $(10,11)$, would not remain undiagnosed, as in our case.

Bullous dermatitis in infants and adults is a clinical term used for several disorders associated with primary neonatal pemphigus. The common symptoms of the disorder regardless of etiologic factors are redness of skin and formation of bubbles of various sizes filled with serous or serous-bloody content. Bursting bubble patches peel off, leaving bare, sometimes oozing surface (12). Bullous dermatitis in neonates and adults associated with primary neonatal pemphigus should be ruled out as a differential diagnosis. It is characterized by irritation and hyperemia of dry skin, with the formation of bubbles with serous or serous-bloody contents, which are emptied and moisturize skin (12).

Immune-Fluorescence-Antigen-Mapping testing is morphological verification of diagnosis and targeted genetic analysis of the mutations by the molecular 
method in Dandy-Walker syndrome (13).

De Crecchio, et al pointed to the association of high myopia and unusual changes in the retina of the eye in Dandy-Walker syndrome (14), which statement authors agree.

Getova and Mihaylova analyzed the effects of Lamotrigine on specific epi-seizure models: neurotransmitters (Glutamate and GABA) are actors in seizure-control, and Lamotrigine has an anticonvulsant effect, reducing intensity and timing of epi-seizures (control with bicuculline and pentylenetetrazole) (15).

Lamotrigine is reported to have linear kinetics so that the elimination rate is linearly proportional to blood concentration. Measurement and close monitoring of lamotrigine levels are vital for discovering new symptoms that could be consistent with lamotrigine toxicity, particularly when the baseline serum concentration is $>10 \mathrm{mg} / \mathrm{l}$ (16), indefinitely to our experience in this case report.

The rate of elimination of Lamotrigine is the linear proportion of its concentration in the blood. Meas- urement of concentration is important for symptom relief and toxicity of Lamotrigine (initial serum concentration $>10 \mathrm{mg} / \mathrm{L}(16))$.

In conclusion, the case report of our adult patient (acute Lamotrigine-overdose) once again confirms that successful treatment of Dandy-Walker syndrome can only be achieved through a multidisciplinary approach, including a medical team consisting of clinical pharmacologist and toxicologist, neurologist, dermatologist, nephrologist, neurosurgeon, ophthalmologist, and social worker. Patients with Dandy-Walker syndrome require adequate socio-medical care of society.

Conflict of Interests: The authors declare that there are no conflicts of interest related to this article.

Funding: None

\section{Licensing}

This work is licensed under a Creative Commons Attribution 4.0 International (CC BY 4.0) License

\title{
Sažetak
}

\section{AKUTNO TROVANJE LAMOTRIGINOM KOD ODRASLIH: PRIKAZ SLUČAJA}

\author{
Janicijevic Katarina ${ }^{1}$, Kovacevic Zoran ${ }^{2}$, Glisic Milos ${ }^{3}$, Janicijevic Petrovic A. Mirjana ${ }^{4}$, \\ Lazarevic Tatjana ${ }^{5}$
}

\begin{abstract}
${ }^{1}$ Department of Social Medicine, Faculty of Medical Sciences University of Kragujevac, Serbia
${ }^{2}$ Department of Internal medicine, Clinical Centre Kragujevac, in Kragujevac, Serbia

${ }^{3}$ Department of Physiology, Faculty of Medical Sciences University of Kragujevac, Serbia

${ }^{4}$ Department of Ophthalmology, Faculty of Medical Sciences University of Kragujevac, Serbia

${ }^{5}$ Department of Internal medicine, Faculty of Medical Sciences University of Kragujevac, Serbia
\end{abstract}

Uvod: Samotrovanje lamotriginom je retko trovanje, nezavisno od suicidne namere bolesnika. Autori prikazuju ilustrativni slučaj bolesnika, koji je lečen (potencijalno kožno-neželjenom terapijom) za epilepsiju, sa Dandy-Walkerovim sindromom i kongenitalnom buloznom dermolizom. Lamotrigin je antiepileptik klase feniltriazina u terapiji bipolarne depresije. Dandy-Walkerov sindrom je patološki entitet i predstavlja skup razvojnih, moždanih, ali i drugih abnormalnosti organizma. Bulozna epidermolize je nasledna, nezapaljenjska bolesti kože i sluzokože sa karakterističnim "mehurićima".

Prikaz bolesnika: Naš bolesnik, star 37 godina prvi put je primljen u hospitalni odsek Centra za urgentnu medicine, Kliničkog Centa Kragujevac u Kragujevcu, jer je konzumirao dve kutije Lamotrigina tableta U prijemnoj ambulanti bolesnik pokazuje respiratornu insuficijenciju, prestanak disanja i u besvesnom stanju je hitno intubiran.
Iz referente medicinske dokumentacije i heteroanamneze (od njegovog oca) saznajemo da je lečen od epilepsije, Dandy-Walkerovim sindroma i kongenitalne bulozne dermolize, koja se se sa terapijom Lamotriginom pogoršala, kroz potencijalno neželjeno dejstvo na koži. U toku kliničke observacije urađena je lavaža želudačnog sadržaja. Kao metod detoksikacije primenjen je medicinski ugalj putem nazogastrične sonde zbog komatoznog stanja svesti bolesnika. Uzročno metabolitičkom putu lamotrigina, sprovedena je hemodijaliza.

Zaključak: Prikaz slučaja ovog bolesnika ukazuje na neophodnost multidiciplinarnog pristupa tima eksperata, u sastavu kliničkog farmakologa i toksikologa, neurologa, dermatologa, nefrologa i drugih specijalista. Pacijenti sa Dandi-Walkerovim sindromom zahtevaju adekvatnu društvenomedicinsku brigu. 
Table 1. The gas, blood and laboratory analyzes (biochemical parameters).

\begin{tabular}{lll}
\hline Gas analyzes & Blood analyzes & Laboratory analyzes \\
\hline $\mathrm{Ph} 7.24$ & Le 11.10 & Glycosa 5.1 \\
$\mathrm{pO}_{2} 6.2$ & Er 3.95 & Urea 1.6 \\
$\mathrm{pCO}_{2} 3.7$ & $\mathrm{Hgb} 124$ & Kreatinin 72 \\
$\mathrm{Na} 139$ & $\mathrm{Hct} 0.327$ & CK 195 \\
$\mathrm{K} 3.3$ & Tr 182 & CRP 15.5 \\
$\mathrm{Ca} 1.14$ & PTT 36.3 & \\
$\mathrm{HCO}_{3} 19.3$ & INR 1.590 & \\
$\mathrm{SpO}_{2} 87 \%$ & Albumin 44 & \\
\hline
\end{tabular}

Ključne reči: Lamotrigin, akutno predoziranje, Dandy-Walker sindrom, kongenitalna bulozna dermoliza, kliničke manifestacije, dijagnostičke i terapijske intervencije

\section{REFERENCES}

1. Griswold A, Tully B, Katz K, Beauchamp G, Cook M, Cannon R. Lamotrigine ODT-induced seizure in a 3-year-old child after accidental ingestion. Case Rep Emerg Med. 2019; 2019: 2675931. doi: $10.1155 / 2019 / 2675931$.

2. Hajiali F, Nassiri-Asl M. Report of severe menorrhagia following the maximum amount of Lamotrigine overdose. Iran J Pharm Res. 2015; 14(4):1289-93.

3. Lambea Gil A, Caldu Agud R, Rodríguez Gascon D, Garayoa Irigoyen V. Encephalopathy secondary to lamotrigine toxicity. Neurologia. 2018; S02134853(18):30146-34. English, Spanish. doi: 10.1016/j. nrl.2018.03.017.

4. Alyahya B, Friesen M, Nauche B, Laliberte M. Acute lamotrigine overdose: a systematic review of published adult and pediatric cases. Clin Toxicol (Phila). 2018; 56(2):81-9. doi: 10.1080/15563650.2017.1370096.

5. Alabi A, Todd A, Husband A, Reilly J. Safety profile of lamotrigine in overdose. Ther Adv Psychopharmacol. 2016; 6(6):369-81. doi: 10.1177/2045125316656707.

6. Bellis TJ, Gibeon L. The use of intralipid emulsion therapy to treat severe cardiotoxicity secondary to lamotrigine ingestion in a dog. Clin Case Rep. 2018; 6(10):1982-8. doi: 10.1002/ccr3.1733.

7. Zamora EA, Ahmad T. Dandy Walker Malformation. Stat Pearls [Internet]. Treasure Island (FL): Stat Pearls Publishing; 2019.

8. Belser-Ehrlich J, Adrian Lafo J, Mangal P, Bradley M, Wicklund M, Bowers D. Neurocognitive profile of a man with Dandy-Walker malformation: evidence of subtle cerebellar cognitive affective syndrome. Clin Neuropsychol. 2020;34(3):591-610. doi:

\subsection{0/13854046.2019.1569724.}

9. Zhang N, Qi Z, Zhang X, Zhong F, Yao H, $\mathrm{Xu} \mathrm{X}$, et al.. Dandy-Walker syndrome associated with syringomyelia in an adult: a case report and literature review. J Int Med Res. 2019; 47(4):1771-7. doi: $10.1177 / 0300060518808961$.

10. Stambolliu E, Ioakeim-Ioannidou M, Kontokostas K, Dakoutrou M, Kousoulis AA. The most common comorbidities in Dandy-Walker syndrome patients: a systematic review of case reports. J Child Neurol. 2017; 32(10):886-902. doi: 10.1177/0883073817712589.

11. Agrawal S, Dave M, Mahur H, Aswani M, Goyal R, Pansari N, et al. Dandy-Walker syndrome: a rare presentation in adult. J Assoc Physicians India. 2016; 64(10): 112 .

12. Konefał H, Gawrych E, Czeszyńska MB. Congenital epidermolysis bullosa - a case report. Ginekol Pol. 2012; 83(10):792-4.

13. Smolyannikova VA, Kubanova AA, Albanova VI, Nefedova MA, Karamova AE. Current approaches to the morphologic diagnosis of different types of congenital epidermolysis bullosa. Arkh Patol. 2016; 78(6):9-16. doi: 10.17116/patol20167869-16.

14. Crecchio G, Cennamo G, de Leeuw N, Ventruto ML, Lonardo MC, Friso P, et al. Severe myopia with unusual retinal anomalies and Dandy-Walker sequence in two sibs. A distinct new neuro-ocular disorder. Ophthalmic Genet. 2013; 34(4):254-7. doi: 10.3109/13816810.2013.763992.

15. Getova DP, Mihaylova AS. A study of the effects of lamotrigine on mice using two convulsive tests. Folia Med (Plovdiv). 2011; 53(2):57-62. doi: 10.2478/v10153010-0038-6.

16. Ramey P, Osborn MR, Lowen KM, Reed RC, Abou-Khalil B. Unexplained spikes in lamotrigine serum concentration: nonlinear elimination? Acta Neurol Scand. 2017; 135(2):240-6. doi: 10.1111/ane.12588. 


\section{Correspondence to/Autor za korespondenciju}

Mirjana A. Janicijevic Petrovic, full professor

Department of Ophthalmology, Faculty of Medical

Sciences University of Kragujevac, Serbia

Svetozara Markovica 69, 34000 Kragujevac, Serbia

E-mail: mira.andreja@yahoo.com

Tel: +381 648065048

Fax: +38134306800 